\title{
VÝVOJ PŮD NA OPUŠTĚNÝCH HALDÁCH PO TĚŽBĚ POLYMETALICKÝCH RUD NA HAVLÍČSKOBRODSKU
}

\author{
Minesoils' evolution on abandoned slag heaps of polymetallic ores \\ in Havlíčkův Brod region
}

\author{
Alexandra Brádlová1, Martin Ivanov', David Buriánek² \\ 1 Ústav geologických věd, Př́rodovědecká fakulta Masarykovy univerzity, Kotlářská 2, 61137 Brno; e-mail: 397212@mail.muni.cz \\ 2Česká geologická služba, Leitnerova 22, 65869 Brno
}

(23-22 Žd’ár nad Sázavou)

Key words: Moldanubian, Havlíčkův Brod mining district, minesoils evolution, slag, polymetallic ores

\begin{abstract}
Old slags situated in the areas of former exploitation of polymetallic ore mineralization are places where initial steps of soil evolution in specific conditions can be investigated. Two soil profiles of different age have been studied in the Utin $\left(2^{\text {nd }}\right.$ half of $13^{\text {th }}$ century to $1^{\text {st }}$ half of the $14^{\text {th }}$ century) and Dlouhá Ves (60's of $20^{\text {th }}$ century) localities. Soil samples of fine fraction were studied including vertical distribution of selected elements ( $\mathrm{Fe}, \mathrm{Pb}, \mathrm{As}, \mathrm{Ag}, \mathrm{Cu} ; \mathrm{AAS})$ in context to other soil parameters including loss on ignition (LOI), sequential extraction analysis (SEA), soil exchangeable acidity $(\mathrm{pH} / \mathrm{KCl})$, mass specific $(\chi)$ and frequency dependent $\left(\chi_{F D}\right)$ magnetic susceptibility. There were higher concentration of $\mathrm{Pb}$ (up to 4,700 ppm), Cu and Ag (both up to 100 ppm) in the Utin soils observed mostly in upper part of the soil profile. Arsenic contamination occurs in entire soil profile with average concentration about 3,000 ppm. In the Dlouhá Ves soils, the higher concentrations of Ag, Cu (about 500 ppm) and As (near 13,000 ppm; $70 \mathrm{~cm}$ ) occur rather in bottom horizons of soil profile. Noticeable positive correlations of LOI vs. $\mathrm{Pb}(r=0.96), \mathrm{Cu}(r=0.90), \mathrm{Fe}(r=0.87), \mathrm{Ag}(r=$ 0.94) together with SEA values from Utin soils indicate that studied elements have in fraction bound to organic matter and sulphides have a tendency to be bound rather to organic compounds. This is the main difference between the two localities because the studied elements in Dlouhá Ves soils have in the same fraction tendency to be bound just to sulphides. In addition to presupposed higher pedogenesis degree in distinctly older Utín soils, the difference between two soil profiles is acidobazic conditions in Dlouhá Ves soil profile, in which the $\mathrm{pH} / \mathrm{KCl}$ is very low. Decomposition of organic matter is also slower in this environment. The lower degree of pedogenesis in Dlouhá Ves is also supported by in average lower values of frequency dependent magnetic susceptibility $\left(\chi_{F D}=1-5 \%\right)$.
\end{abstract}

\section{Úvod}

Staré haldy dokládající někdejší těžbu rud v rámci polymetalického zrudnění představují prostředí, ve kterém můžeme ve specifických podmínkách studovat raná stadia vývoje půd. Vývoj půd je na těchto místech oproti půdám vznikajícím na přirozeném substrátu urychlen antropogenním rozrušením matečné horniny (Sencindiver - Ammons 1997), přičemž specifický chemismus půdotvorného substrátu může výrazně ovlivnit vývoj celého profilu (Bussinow et al. 2012; Karczewska et al. 2006). Tato studie si klade za cíl podrobněji popsat, jaké faktory ovliv-

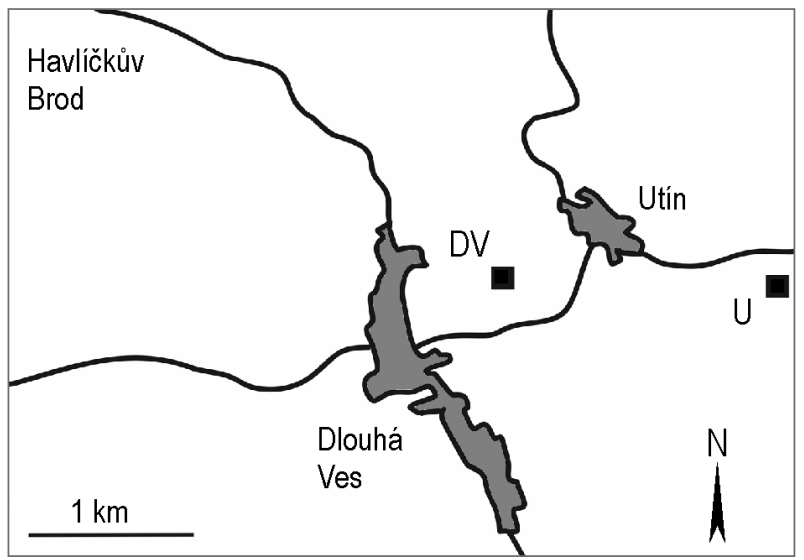

Obr. 1: Topografická pozice studovaných profilů na Havlíčskobrodsku (U - Utín, DV - Dlouhá Ves).

Fig. 1: Topographical position of studied soil profiles in Havlíčkův Brod region (U - Utín, DV - Dlouhá Ves). ňují pedogenetický proces na dnes již opuštěných haldách po těžbě polymetalických rud na Havlíčskobrodsku. Zvoleny byly dvě haldy různého stárí (obr. 1), a to na lokalitách Utín (2. polovina 13. stol. až 1. pol. 14. stol.; Stránský et al. 2002) a Dlouhá Ves (60. léta 20. stol.; Dobeš - Malý 2001; Kocourková et al. 2008).

\section{Geologická a pedologická charakteristika oblasti}

Studované lokality leží v havličkobrodském rudním revíru, jenž je situován v moldanubiku. Tato geologická jednotka je budována hlavně středně a vysoce metamorfovanými horninami (především migmatity), které jsou pronikány řadou typů plutonických hornin, mezi nimiž dominují granity (Mísař et al. 1983).

Na geologické stavbě havlíčskobrodského rudního revíru se podílejí pararuly (biotit-granátické, biotitické nebo sillimanit-biotitické) a často i menší tělesa s.-j. orientovaných amfibolitů, vyskytující se především na východ od Stř́brných hor. Lokálně je vyvinuta silná migmatitizace, která postihuje hlavně ruly (Dobeš - Malý 2001; Beneš et al. 1996). Mezi obcemi Utín a Dlouhá Ves je situováno těleso serpentinitu. Na východ od Stř́brných hor byly popsány výskyty slepenců. Sedimentární pokryv je v malé míre tvořen také eluvii, svahovými hlínami a říčními terasami (Juráček 2010).

Hydrotermální polymetalické zrudnění na obou studovaných lokalitách bylo ovlivněno disjunktivní tektonikou tř́ směrů. Jedná se o systémy zlomů ve směru SSZ-JJV až SSV-JJZ (přibyslavsko-dačické mylonitové 
pásmo); směru SZ-JV (sázavský zlom) a Z-V směru křídelského zlomu (Králík et al. 1985). V celém havlíčkobrodském rudním revíru dominuje kyzová polymetalická asociace s výskyty sfaleritu, méně galenitu a karbonátů (Bernard 2000).

V zájmové oblasti jsou rozsáhlé výskyty různých subtypů kambizemí (kambizem mesobazická až oglejená), v menší míře jsou vyvinuty pseudogleje a gleje. Lokálně lze popsat i výskyty železitých subtypů podzolů. Studované lokality jsou situovány zhruba na pomezí výskytu podzolů a kambizemí (Čech 2002; ČGS 2012). Výskyty kambizemí lze vysvětlit pestrým geologickým podložím, jež je tvořeno rulami, granity a bazalty až po pískovce, břidlice či štěrky. Podzoly vznikají výhradně na rulách, svorech apod. (Němeček 2001).

\section{Doklady těžby polymetalických rud na lokalitách Utín a Dlouhá Ves}

Utín: Lokalita Utín-Poperk je situována asi $1 \mathrm{~km}$ jv. od obce Utín, v různě migmatizovaných biotitických až sillimanit-biotitických pararulách, poblíž leží menší amfibolitová tělesa (Beneš et al. 1996). V materiálu po středověké těžbě jsou rudní minerály nacházeny jen v malém množství, k nejčastějším patří galenit, pyrit, pyrhotin, sfalerit, chalkopyrit (Stránský et al. 2002; Vávra et al. 2008). $\mathrm{V}$ haldách jsou známy hydrotermální přeměny hornin spojené s rozkladem živců a biotitu, pyritizací, limonitizací, aj. (Vávra et al. 2008).

Dlouhá Ves: Halda u Dlouhé Vsi je asi $200 \mathrm{~m}$ s. od křižovatky mezi Utínem a Dlouhou Vsí. Je situována poblíž utínského serpentinitového tělesa a leží v biotitických až sillimanit-biotitických pararulách až migmatitech (Hak - Novák 1973). Byly zde popsány především minerály arzenopyrit, pyrhotin, sfalerit, pyrit, galenit, chalkopyrit a křemen (Hak - Novák 1973; Dobeš - Malý 2001). Ze všech ložisek v havlíčkobrodském rudním revíru se na ložisku Dlouhá Ves vyskytuje nejvíce supergenních minerálů. Během zvětrávacích procesů došlo $\mathrm{k}$ přeměně sulfidů, např́íklad na kaňkit, jarosit, malachit, farmakosiderit, nebo limonitické oxidy a hydroxidy (Pauliš et al. 2011; Kocourková et al. 2008).

\section{Metodika}

Na lokalitách Utín (49³5'1.7874“N, $\left.15^{\circ} 42^{\prime} 7.2354^{\prime \prime} \mathrm{E}\right)$ a Dlouhá Ves $\left(49^{\circ} 35^{\prime} 5.2434^{\prime \prime N}\right.$, $15^{\circ} 40^{` 3} 3.496^{\prime \prime E)}$ byly vykopány a zdokumentovány půdní sondy přibližně $100 \mathrm{~cm}$ hluboké a $50 \mathrm{~cm}$ široké. $Z$ obou sond byly s krokem $10 \mathrm{~cm}$ ve vertikálním směru až do hloubky $70 \mathrm{~cm}$ odebrány vzorky půd k následným analýzám (obr. 2). Z odebraných vzorků vysušených při pokojové teplotě do konstantní hmotnosti byla pomocí síta o průměru ok $2 \mathrm{~mm}$ vyseparována jemnozem, jež byla zbavena organického detritu.

$\mathrm{Na}$ vzorcích jemnozemě o váze přibližně $20 \mathrm{~g}$ byla měřena hmotnostně specifická magnetická susceptibilita $\chi\left[\mathrm{m}^{3} \mathrm{~kg}^{-1}\right]$ a frekvenčně závislá susceptibilita $\chi_{\mathrm{FD}}$, (Dearing 1994; Dearing et al.
1996) přičemž $\chi_{\mathrm{FD}}[\%]=100 \times\left(\chi_{\mathrm{LF}}-\chi_{\mathrm{HF}}\right)$, kde $\left(\chi_{\mathrm{LF}}-\chi_{\mathrm{HF}}\right)$ je rozdíl hodnot naměřených při nízké $\left(\chi_{\mathrm{LF}}\right)$ a vysoké $\left(\chi_{\mathrm{HF}}\right)$ frekvenci. Magnetická susceptibilita byla na přístroji MFK1-FA (AGICO, a. s.) měřena na frekvencích $976 \mathrm{~Hz}$, 3904 Hz a 15616 Hz. Barva vysušených vzorků byla určena pomocí Munsellovy barevné škály (Munsell Color System). Pedochemické analýzy u všech vzorků zahrnovaly ztrátu žíháním (LOI, loss on ignition) při $550^{\circ} \mathrm{C}$ a $1000^{\circ} \mathrm{C}$, stanovení $\mathrm{pH} / \mathrm{KCl}$ (ČSN ISO 10390) a prvkovou analýzu (Fe, Pb, As, $\mathrm{Ag}, \mathrm{Cu})$ ze vzorků rozpuštěných ve směsi $\mathrm{HF}+\mathrm{HClO}_{4}$, použitím AAS (Solaar M5 od společnosti TJA Solutions). Sekvenční extrakční analýza (SEA) byla na obou půdních profilech provedena pouze u vzorků z hloubek 20, 50 a 70 cm (Utín: U-20, U-50, U-70; Dlouhá Ves: DV-10, DV50, DV-70). SEA vychází z postupu uvedeného Tessierem et al. (1979): 1) vyměnitelná frakce se extrahovala v roztoku $\left.1 \mathrm{~mol} \mathrm{MgCl}_{2} ; 2\right)$ frakce vázáná na karbonáty se loužila pomocí $1 \mathrm{~mol} \mathrm{l}^{-1} \mathrm{CH}_{3} \mathrm{COONa}$; 3 ) frakce vázaná na oxidy a hydroxidy $\mathrm{Fe}$ a Mn se získala loužením v roztoku $\mathrm{NH}_{2} \mathrm{OH}$. $\mathrm{HCl}$ v 25\% $\mathrm{CH}_{3} \mathrm{COOH}$; 4) frakce vázaná na organiku se sulfidy byla získána loužením v $\mathrm{HNO}_{3} \mathrm{a} \mathrm{H}_{2} \mathrm{O}_{2}$ při $\mathrm{T}=85^{\circ} \mathrm{C}$, a poté loužením v $\mathrm{C}_{2} \mathrm{H}_{3} \mathrm{O}_{2} \mathrm{NH}_{4}$ ve $20 \% \mathrm{HNO}_{3}$.

\section{Výsledky \\ Popis půdních profilu}

Oba studované půdní profily jsou vyvinuty z matečného substrátu tvořeného biotitickými až sillimanit-biotitickými pararulami až migmatity. V nejbližším okolí studovaných hald byla zjištěna převaha mesobazických typů kambizemí, místy oglejených, na lokalitě Dlouhá Ves byla na s. okraji haldy $\mathrm{v}$ intaktních horninách ověřena přítomnost železitých subtypů podzoli̊. Půdní profil na lokalitě Utín je výrazně diferencovaný s ostře ohraničenými půdními horizonty. Půdní profil O-Ah-Bvs-C odpovídá subtypu kambizemě dystrické s náznakem

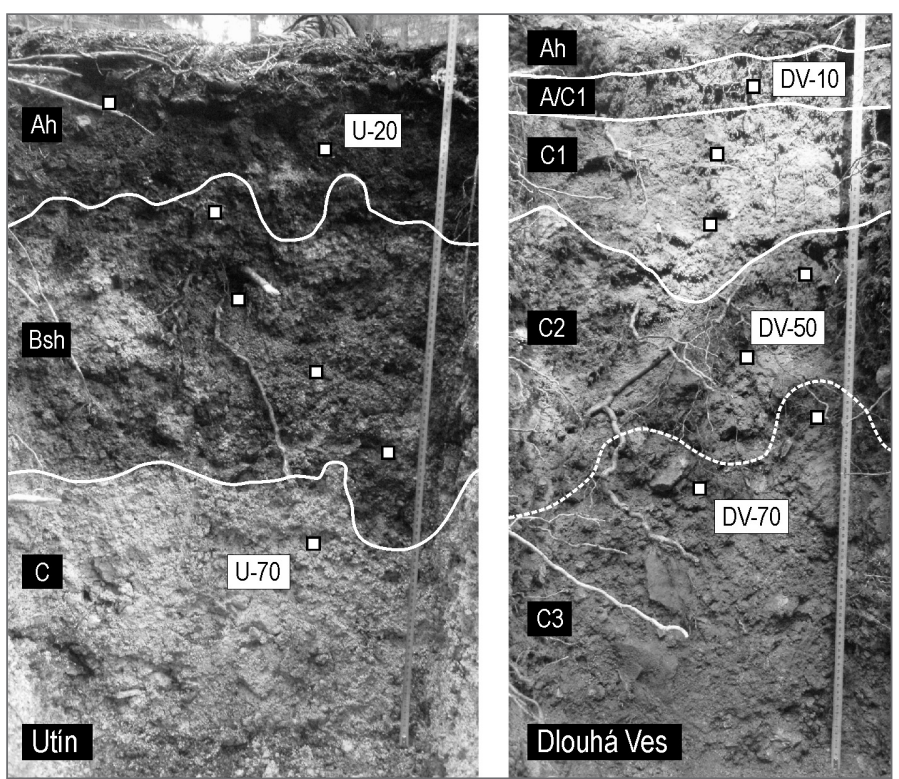

Obr. 2: Půdní profily na lokalitách Utín a Dlouhá Ves s místy odběrů půdních vzorků.

Fig. 2: Soil profiles at Utín and Dlouhá Ves sites with positions of soil samples. 
Tab. 1: Popis půdních profilů na lokalitách Utín a Dlouhá Ves. Tab. 1: Description of soil profiles at Utín and Dlouhá Ves sites.

\begin{tabular}{|c|c|}
\hline Utín-Poperek (U) & Dlouhá Ves (DV) \\
\hline $\begin{array}{l}\text { Ah: } 0-20 \mathrm{~cm} \text {, tmavě hnědý hlinitý písek až písčitá hlína (Munsell } \\
\text { Color System } 10 \text { YR } 3 / 3 \text { ), struktura středně drobtová, bez větších } \\
\text { zbytkủ vegetace, príměs skeletu do } 10 \% \text { (ploché ostrohranné úlomky } \\
\text { štěrkové frakce do } 4 \mathrm{~cm} \text {, rozpadlé biotitické ruly), na bázi ostrý pře- } \\
\text { chod do horizontu Bvs. }\end{array}$ & $\begin{array}{l}\text { Ah: } 0-4 \mathrm{~cm} \text {, velmi tmavě šedý hlinitý písek (Munsell Color System } \\
\text { 10YR 3/1), bez struktury, výrazný podíl částečně dekomponovaných } \\
\text { zbytků jehličí, listù a kưry stromù, bez skeletovitosti (bez úlomkù } \\
\text { hornin), dobře patrný přechod do horizontu A/C1. }\end{array}$ \\
\hline $\begin{array}{l}\text { Bvs: } 20-60 \mathrm{~cm} \text {, hnědá písčitá hlína (Munsell Color System } 10 \text { YR } 5 / 3 \text { ), } \\
\text { struktura náznakem drobně polyedrická, bez vegetace, slabá skeletovi- } \\
\text { tost do } 20 \% \text { (převážně zaoblené, ale se značným podílem ostrohran- } \\
\text { nějších úlomků navětralých rul, od jemně zrnitého štěrku až do } 5 \mathrm{~cm} \text { ), } \\
\text { na bázi dobře viditelný zvlněný přechod do horizontu C. }\end{array}$ & $\begin{array}{l}\text { A/C1: } 4-10 \mathrm{~cm} \text {, šedohnědý hlinitý písek (Munsell Color System 10YR } \\
\text { 5/2), bez struktury, menší podíl částečně dekomponovaných organic- } \\
\text { kých zbytkủ, bez skeletovitosti, ostrý přechod do horizontu C1. }\end{array}$ \\
\hline \multirow[t]{2}{*}{$\begin{array}{l}\text { C: } 60-100 \mathrm{~cm} \text {, světle šedá písčitá hlína (Munsell Color System } 5 \mathrm{Y} \\
7 / 2) \text {, struktura náznakem drobně polyedrická, bez vegetace, střední } \\
\text { skeletovitost ( } 30 \% \text { skeletu, převaha zaobleného jemnozrnného štěrku } \\
\text { silně zvětralých rul, výskyt i středně zrnitého až velmi hrubě zrnitého } \\
\text { o prủměru } 1,5-6,0 \mathrm{~cm}) \text {. }\end{array}$} & $\begin{array}{l}\text { C1: } 10-30 \mathrm{~cm} \text {, žlutohnědý hlinitý písek (Munsell Color System } 10 \mathrm{YR} \\
5 / 6) \text {, jemnè polyedrická (hrudovitá) struktura, střední skeletovitost } \\
(35 \% \text { ostrohranných úlomkủ navětralých rul o velikostech } 0,5-2 \mathrm{~cm} \text { ), } \\
\text { viditelné kořínky rostlin, na bázi ostrý přechod do horizontu C2 s } \\
\text { vyšším podílem půdního skeletu. }\end{array}$ \\
\hline & $\begin{array}{l}\text { C2/C3: } 30-70 \mathrm{~cm} \text {, žlutohnědá písčitá hlína až hlinitý písek (Munsell } \\
\text { Color System } 10 \text { YR } 5 / 6 \text { ), struktura stř́edně hrudovitá, stř́ední až silná } \\
\text { skeletovitost ( } 50 \% \text { skeletu, převážně ostrohranné úlomky navětralých } \\
\text { rul od velikosti } 2-5 \mathrm{~mm} \text {, směrem k bázi úlomky až do } 10 \mathrm{~cm} \text { ), ve } \\
\text { vrchní části ještě viditelné kořínky rostlin. }\end{array}$ \\
\hline
\end{tabular}

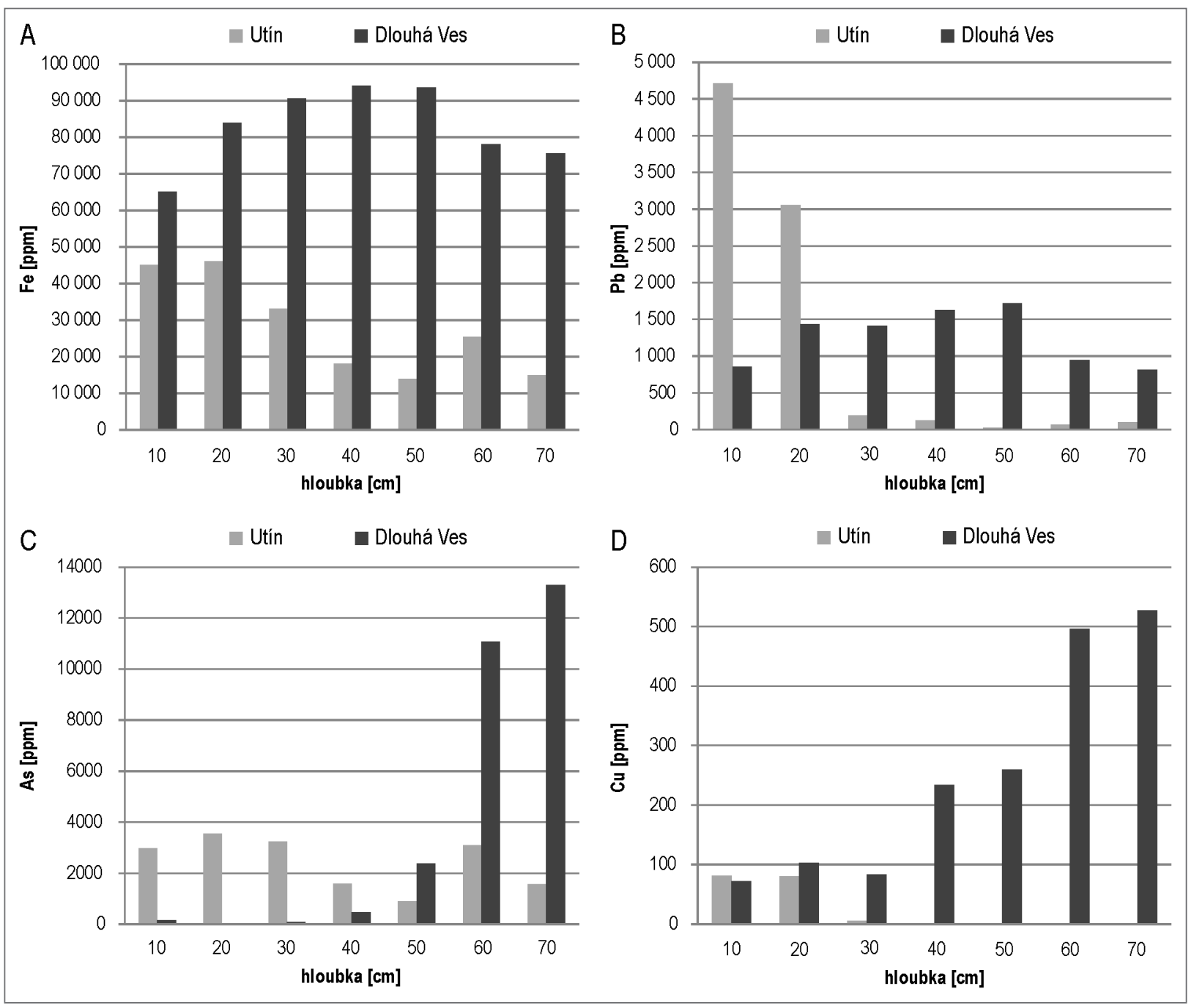

Obr. 3: Koncentrace Fe, $\mathrm{Pb}$, As a Cu v půdních profilech na lokalitách Utín a Dlouhá Ves.

Fig. 3: Concentrations of $\mathrm{Fe}, \mathrm{Pb}$, As and $\mathrm{Cu}$ within soil profiles at Utín and Dlouhá Ves sites. 


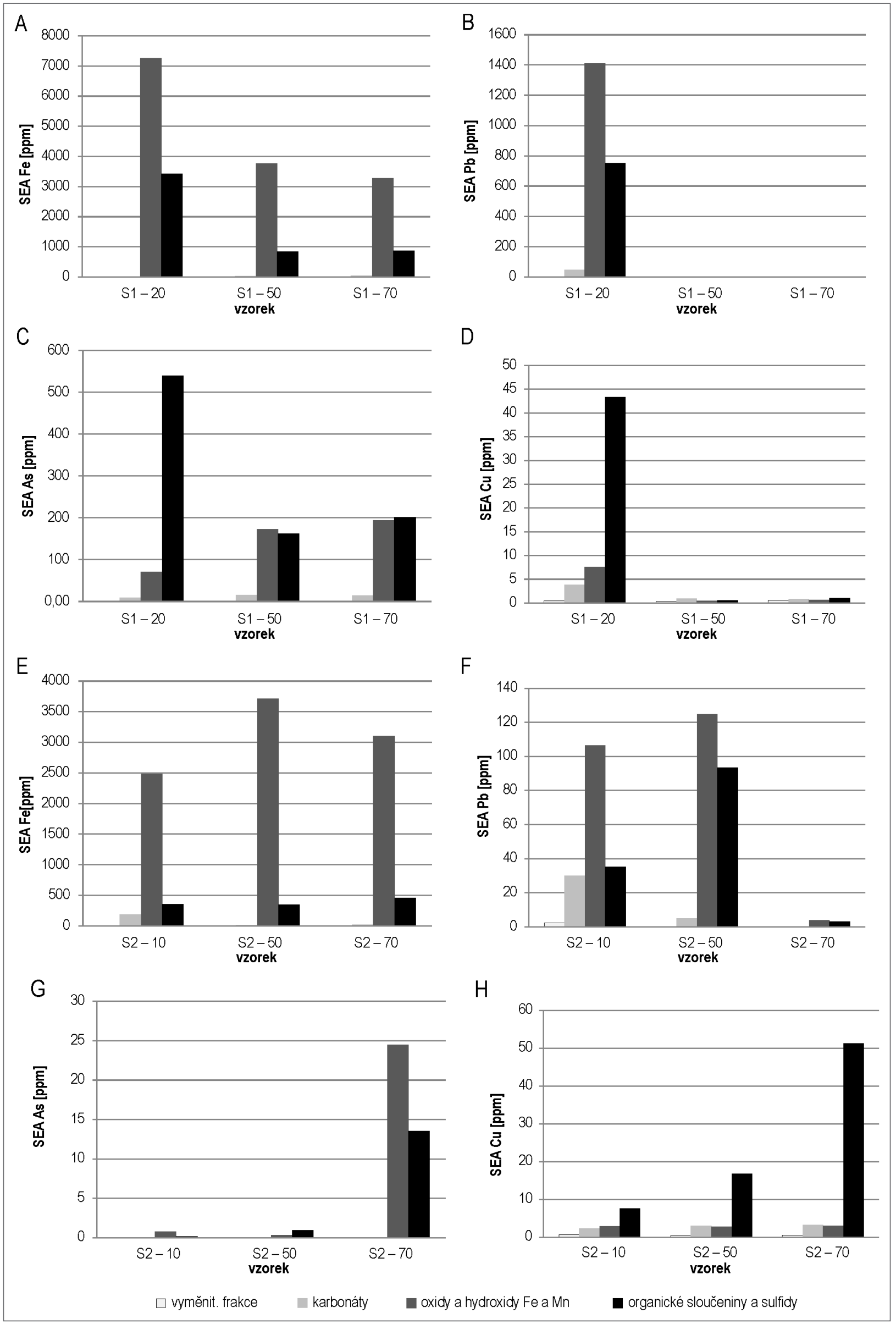

Obr. 4: Výsledky SEA z půdních vzorků z lokalit Utín (A-D) a Dlouhá Ves (E-G).

Fig. 4: Results of SEA from soil samples at Utín (A-D) and Dlouhá Ves (E-G) sites. 
slabého podzolizačního procesu. Na lokalitě Dlouhá Ves půdní profil odpovídá iniciálnímu vývoji půdy s velmi krátkým časovým vývojem, čemuž odpovídá i absence vyvinutého B-horizontu: O-Ah-A/C1-C1-C2/C3. Detailní popis půdních profilů z lokalit Utín a Dlouhá Ves (obr. 2) je uveden $v$ tabulce 1 .

\section{Prvková analýza}

Koncentrace Fe ve vzorcích z lokality Utín dosahují v prvních $20 \mathrm{~cm}$ přibližně $45000 \mathrm{ppm}$ (obr. 3A; tab. 2). Se zvyšující se hloubkou koncentrace systematicky klesá k hodnotám kolem 15000 ppm (s drobnými výkyvy např. v hloubce $60 \mathrm{~cm}$ ). Podobný trend vykazuje i Pb (obr. 2B). Koncentruje se hlavně při povrchu (3 000-4 700 ppm), směrem $\mathrm{k}$ bázi profilu jeho koncentrace prudce klesá. U As byly nejvyšší koncentrace (cca 3000 ppm) zjištěny v hloubkách $10-30 \mathrm{~cm}$ a $60 \mathrm{~cm}$ (obr. 3C). V porovnání s Fe jsou koncentrace $\mathrm{Pb}$ a As $\mathrm{v}$ sondě na lokalitě Utín nižší (obr. 3B, C). Koncentrace $\mathrm{Cu}$ a $\mathrm{Ag}$ (tab. 2) nepřesáhly 85 ppm, přičemž vyšší koncentrace obou prvků byly při povrchu sondy (obr. 3D). Koncentrace mědi ve vzorcích z 40-70 cm byly pod mezí detekce.

$\mathrm{V}$ případě vzorků z lokality Dlouhá Ves se projevily nejvyšší koncentrace rovněž u prvků $\mathrm{Fe}, \mathrm{Pb}$ a As (obr. 3AC; tab. 2). Nejvyšší koncentrace Fe (kolem 90000 ppm) se objevují ve vzorcích z houbky $30-50 \mathrm{~cm}$, v ostatních vzorcích hodnoty neklesají pod 65000 ppm. Také u Pb je možné pozorovat nejvyšší koncentrace v 20-50 cm (1400-1 700 ppm), v ostatních vzorcích jeho koncentrace nepřesáhly $950 \mathrm{ppm}$. Arsen se koncentruje spíše ve spodních částech profilu, kde dosahuje extrémní hodnoty až $13000 \mathrm{ppm}$. V prvních $40 \mathrm{~cm}$ jsou koncentrace As přibližně jen 30-500 ppm. Koncentrace $\mathrm{Cu}(\max .527$ ppm) a Ag (max. cca 100 ppm) jsou ve srovnání s As podstatně nižší (obr. 3D).

\section{Sekvenční extrakční analýza}

Výsledky sekvenční extrakční analýzy (SEA) ukazují (obr. 4AH; tab. 3), že ve vzorcích z půdního profilu u Utína se $\mathrm{Pb}$ s Fe vyskytují většinou ve frakci vázané na oxi-hydroxidy Fe a Mn, v menší míře i na organiku a sulfidy (obr. 4A, B). As a také $\mathrm{Cu}$ (v Ah-horizontu) mají tendenci se vázat hlavně na organické sloučeniny a na sulfidy, ve spodních částech profilu má As tendenci vázat se ve stejné míře i na organické sloučeniny a sulfidy. Obsahy $\mathrm{Cu}$ jsou v hloubce $30-70 \mathrm{~cm}$ natolik nízké, že výsledky SEA nedávají jednoznačný výsledek (obr. 4C, D).

Ve vzorcích z lokality Dlouhá Ves jsou $\mathrm{Pb}$ a Fe, podobně jako na lokalitě Utín, vázány především na oxi-hydroxidy Fe a $\mathrm{Mn}$. Pb vykazuje tendenci vázat se významně na organické látky, ve vyšší části profilu i na karbonáty (obr. $4 \mathrm{E}, \mathrm{F})$. Ag se zde váže pouze s organickými sloučeninami a sulfidy (tab. 3). As se váže hlavně na oxi-hydroxidy Fe a Mn, méně na organické látky a sulfidy (ve vzorku z hloubky $50 \mathrm{~cm}$ však převažuje vazba na organické sloučeniny a sulfidy. Cu je vázána hlavně na organické látky a sulfidy (obr. 4G, H).

\section{Hmotnostně specifická a frekvenčně závislá susceptibilita}

Ve vzorcích z lokality Utín byla zjištěna nejvyšší hodnota hmotnostně specifické susceptibility $\chi$ (obr. 5A; tab 1) prri povrchu $\left(17 \times 10^{-8} \mathrm{~m}^{3} \mathrm{~kg}^{-1}\right)$. S rostoucí hloubkou (od $30 \mathrm{~cm}$ ) se hodnoty snížily na $2,5-5 \times 10^{-8} \mathrm{~m}^{3} \mathrm{~kg}^{-1}$. Ve vzorcích sondy u Dlouhé Vsi jsou hodnoty vyšší, $\chi$ se v celém profilu pohybuje okolo $1,2-3,2 \times 10^{-7} \mathrm{~m}^{3} \mathrm{~kg}^{-1}$, pouze ve vzorku z $30 \mathrm{~cm}$ se hodnota výrazně zvýšila $(6,2 \times$ $\left.10^{-7} \mathrm{~m}^{3} \mathrm{~kg}^{-1}\right)$.

Ve vzorcích ze sondy 01-Utín dosahují hodnoty frekvenčně závislé susceptibility $\left(\chi_{F D}\right)$ rozsahu 2-6\%. Nejnižší hodnota $\chi_{\mathrm{FD}}$ byla zjištěna v hloubce $20 \mathrm{~cm}$, nejvyšší v $70 \mathrm{~cm}$. V sondě u Dlouhé Vsi vykazuje $\chi_{\mathrm{FD}}$ vyšší hodnoty při povrchu $(4 \%)$ a na bázi $(5 \%$ v $70 \mathrm{~cm})$ s výrazným poklesem ve $30 \mathrm{~cm} \mathrm{(1 \% ;} \mathrm{obr.} \mathrm{5B;} \mathrm{tab.} 1)$.

\section{Výměnná půdní reakce $(p \mathrm{H} / \mathrm{KCl})$}

Hodnoty $\mathrm{pH} / \mathrm{KCl}$ (tab. 1) ve vzorcích $\mathrm{z}$ profilu u Utína většinou vykazují kyselou reakci v rozmezí cca $3,6-5,5$. Nejvyšší hodnota byla zjištěna ve $20 \mathrm{~cm}$, poté pH/
Tab. 2: Výsledky analýz půdních vzorků z lokalit Utín a Dlouhá Ves. Tab 2: Results of soil samples analyses from Utín and Dlouhá Ves sites.

\begin{tabular}{|l|c|c|c|c|c|c|c|}
\hline vzorky - Utín & $\mathrm{U}-10 \mathrm{~cm}$ & $\mathrm{U}-20 \mathrm{~cm}$ & $\mathrm{U}-30 \mathrm{~cm}$ & $\mathrm{U}-40 \mathrm{~cm}$ & $\mathrm{U}-50 \mathrm{~cm}$ & $\mathrm{U}-60 \mathrm{~cm}$ & $\mathrm{U}-70 \mathrm{~cm}$ \\
\hline $\mathrm{LOI} 550{ }^{\circ} \mathrm{C}[\%]$ & 9,9 & 6,4 & 4,3 & 3,1 & 3,1 & 4,2 & 2,8 \\
\hline $\mathrm{LOI} 1000^{\circ} \mathrm{C}[\%]$ & 11,1 & 7,7 & 5,4 & 3,8 & 3,8 & 5,2 & 3,4 \\
\hline $\mathrm{pH} / \mathrm{KCl}$ & 3,6 & 5,5 & 5,0 & 4,7 & 4,5 & 4,4 & 4,3 \\
\hline$\chi\left[\mathrm{m}^{3} \mathrm{~kg}^{-1}\right]$ & $1,8 \mathrm{E}-07$ & $1,4 \mathrm{E}-07$ & $5,0 \mathrm{E}-08$ & $2,9 \mathrm{E}-08$ & $2,3 \mathrm{E}-08$ & $3,8 \mathrm{E}-08$ & $2,5 \mathrm{E}-08$ \\
\hline$\chi_{\mathrm{FD}}[\%]$ & 5,1 & 2,3 & 3,4 & 5,0 & 3,4 & 3,6 & 6,0 \\
\hline $\mathrm{Fe}[\mathrm{ppm}]$ & 45105 & 46084 & 33007 & 17972 & 13846 & 25455 & 14825 \\
\hline $\mathrm{Cu}[\mathrm{ppm}]$ & 81 & 80 & 6 & 0 & 0 & 0 & 0 \\
\hline $\mathrm{Pb}[\mathrm{ppm}]$ & 4711 & 3049 & 192 & 125 & 30 & 66 & 102 \\
\hline $\mathrm{Ag}[\mathrm{ppm}]$ & 82 & 71 & 36 & 33 & 34 & 32 & 34 \\
\hline $\mathrm{As}[\mathrm{ppm}]$ & 2965 & 3544 & 3236 & 1596 & 888 & 3108 & 1561 \\
\hline $\mathrm{vzorky}-\mathrm{Dl} . \mathrm{Ves}$ & $\mathrm{DV}-10 \mathrm{~cm}$ & $\mathrm{DV}-20 \mathrm{~cm}$ & $\mathrm{DV}-30 \mathrm{~cm}$ & $\mathrm{DV}-40 \mathrm{~cm}$ & $\mathrm{DV}-50 \mathrm{~cm}$ & $\mathrm{DV}-60 \mathrm{~cm}$ & $\mathrm{DV}-70 \mathrm{~cm}$ \\
\hline $\mathrm{LOI} \mathrm{550}{ }^{\circ} \mathrm{C}[\%]$ & 5,4 & 5,6 & 6,9 & 6,4 & 6,4 & 5,6 & 5,8 \\
\hline $\mathrm{LOI} \mathrm{1000}{ }^{\circ} \mathrm{C}[\%]$ & 6,6 & 7,5 & 9,4 & 8,2 & 8,2 & 7,0 & 7,1 \\
\hline $\mathrm{pH} / \mathrm{KCl}$ & 3,2 & 3,0 & 3,3 & 3,1 & 3,1 & 3,0 & 3,0 \\
\hline$\chi\left[\mathrm{m}^{3} \mathrm{~kg}{ }^{-1}\right]$ & $3,0 \mathrm{E}-07$ & $3,3 \mathrm{E}-07$ & $6,3 \mathrm{E}-07$ & $2,9 \mathrm{E}-07$ & $3,1 \mathrm{E}-07$ & $1,7 \mathrm{E}-07$ & $1,3 \mathrm{E}-07$ \\
\hline$\chi_{\mathrm{FD}}[\%]$ & 3,8 & 2,5 & 1,2 & 1,6 & 2,2 & 3,9 & 5,3 \\
\hline $\mathrm{Fe}[\mathrm{ppm}]$ & 65105 & 83916 & 90629 & 94126 & 93497 & 78042 & 75594 \\
\hline $\mathrm{Cu}[\mathrm{ppm}]$ & 72 & 103 & 83 & 234 & 259 & 496 & 527 \\
\hline $\mathrm{Pb}[\mathrm{ppm}]$ & 858 & 1435 & 1414 & 1630 & 1716 & 948 & 811 \\
\hline $\mathrm{Ag}[\mathrm{ppm}]$ & 31 & 33 & 33 & 42 & 52 & 88 & 101 \\
\hline $\mathrm{As}[\mathrm{ppm}]$ & 155 & 33 & 93 & 465 & 2381 & 11065 & 13302 \\
\hline
\end{tabular}




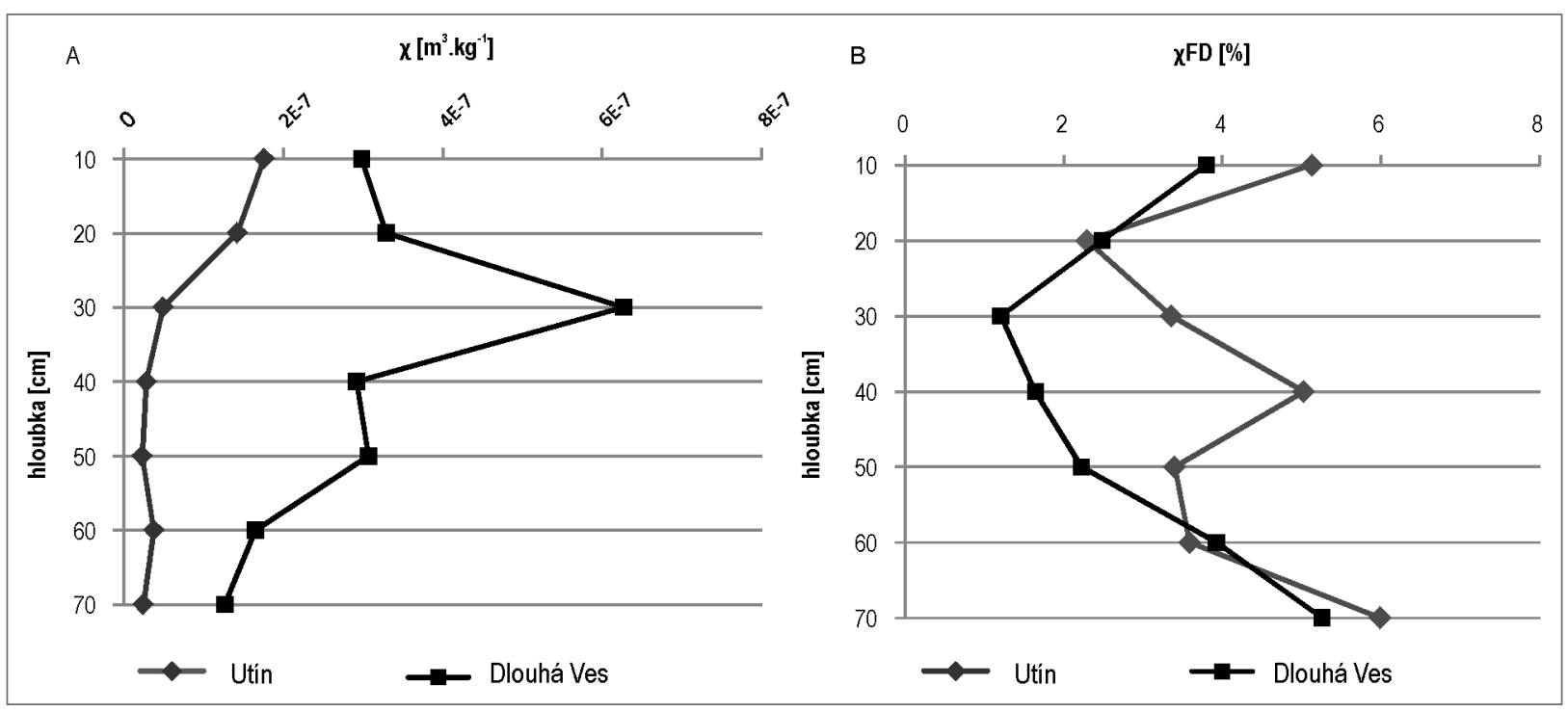

Obr. 5: Magnetická susceptibilita hmotnostně specifická (A) a frekvenčně závislá (B) v půdních profilech na lokalitách Utín a Dlouhá Ves. Fig. 5: Mass (A) and frequency-dependent (B) magnetic susceptibility in soil profiles at Utín and Dlouhá Ves sites.

$\mathrm{KCl}$ systematicky klesá (pH/KCl = 4,5 v 70 cm). Nejnižší hodnota $(\mathrm{pH} / \mathrm{KCl}=3,5)$ byla zjištěna v nejsvrchnější části profilu. Na lokalitě Dlouhá Ves se naměřené hodnoty v celém půdním profilu pohybují kolem $\mathrm{pH} / \mathrm{KCl} \sim 3$ (obr. 6).

\section{Diskuze}

V půdním profilu na lokalitě Utín je množství Fe většinou o několik řádů nižší než na lokalitě Dlouhá Ves. V profilu sondy na lokalitě Utín vykazují všechny zkoumané prvky nejvyšší koncentrace při povrchu horizontu. Koncentrace $\mathrm{Pb}$ i As mnohonásobně převyšují maximální povolený limit pro lehké půdy stanovený vyhláškou MŽP, který je 100 ppm pro $\mathrm{Pb}$ a $30 \mathrm{ppm}$ pro As (MŽP 2014). V půdním profilu u Dlouhé Vsi se koncentrace některých prvků (As, Cu) zvyšuje směrem do hloubky, přičemž nejvyšších hodnot dosahují tyto prvky v hloubkách 60-70 cm. I zde jsou limitní hodnoty povolených koncentrací Pb, As a Cu (MŽP 2014) velmi výrazně překročeny, což platí především pro As (limit překročen více než 440 krát). Zvýšené riziko kontaminace podzemních vod a vegetačního krytu je patrné především $\mathrm{v}$ prrípadě profilu u Dlouhé Vsi, $\mathrm{k}$ čemuž přispívá velmi nízké $\mathrm{pH}$ ( 3-3,3; obr. 6), kdy se výrazně zvyšuje pohyb amorfních Fe-Mn komplexů (Gobat et al. 2004).

$\mathrm{Na}$ obou studovaných lokalitách statisticky $(\mathrm{N}=7, \mathrm{p}<0,05)$ silně pozitivně korelují $\mathrm{Pb}$ vs. $\mathrm{Fe}$ a $\mathrm{Cu}$ vs. Ag (obr. 7). V profilu na lokalitě Utín mají $\mathrm{Fe}$ a $\mathrm{Pb}$ tendenci vázat se převážně na oxi-hydroxidy Fe a $\mathrm{Mn}$, zatímco $\mathrm{Cu}$ a As se vážou především na organické sloučeniny a sulfidy (obr. 4A-D). Silně pozitivní korelace LOI vs. $\mathrm{Pb}(\mathrm{r}=0,96)$, $\mathrm{Cu}(\mathrm{r}=0,90), \mathrm{Fe}(\mathrm{r}=0,87), \mathrm{Ag}(\mathrm{r}=0,94)$ dokládá, že u zmíněných prvků (neplatí pro As) ve frakci vázané na organiku a sulfidy výrazně převažuje tendence vázat se na organické sloučeniny (obr. $8 \mathrm{~A}, \mathrm{~B})$. Tím se půdní profil u Utína výrazně odlišuje od profilu u Dlouhé Vsi, kde absence korelace koncentrací zmíněných prvků s LOI (s výjimkou Fe, kde r $=0,84$ ) ukazuje, že prvky ve frakci organických sloučenin a sulfidů (s výjimkou As) mají tendenci vázat se především na sulfidy. Podstatnou roli ve vazbě sledovaných prvků s organickými sloučeninami zřejmě hraje množství rozložené organiky (viz LOI, tab. 2) a s tím související tvorba převážně organických komplexů (Gobat et al. 2004), jejichž přítomnost dokládá dobře vyvinutá středně drobtová struktura tmavě hnědě zbarveného Ah-horizontu na haldě

Tab. 3: Výsledky sekvenčních extrakčních analýz půdních vzorků z lokalit Utín a Dlouhá Ves.

Tab. 3: Results of sequential extraction analyses of soil samples from Utín and Dlouhá Ves sites.

\begin{tabular}{|c|c|c|c|c|c|c|}
\hline SEA & $\begin{array}{c}\mathrm{U}-20 \mathrm{~cm} \\
(\mathrm{Ah})\end{array}$ & $\begin{array}{c}\mathrm{U}-50 \mathrm{~cm} \\
\text { (Bvs) }\end{array}$ & $\begin{array}{c}\mathrm{U}-70 \mathrm{~cm} \\
\text { (C) }\end{array}$ & $\begin{array}{c}\mathrm{DV}-10 \mathrm{~cm} \\
(\mathrm{Ah})\end{array}$ & $\begin{array}{c}\mathrm{S} 2-50 \mathrm{~cm} \\
(\mathrm{C} 2)\end{array}$ & $\begin{array}{c}\mathrm{S} 2-70 \mathrm{~cm} \\
\text { (C3) }\end{array}$ \\
\hline \multicolumn{7}{|c|}{ 1. běh (vyměnitelná frakce) } \\
\hline $\mathrm{Cu}$ & 0,4 & 0,4 & 0,6 & 0,7 & 0,5 & 0,5 \\
\hline $\mathrm{Pb}$ & 2,1 & 0,1 & 0,0 & 2,3 & 0,2 & 0,0 \\
\hline $\mathrm{Ag}$ & 0,0 & 0,0 & 0,0 & 0,0 & 0,0 & 0,0 \\
\hline $\mathrm{Fe}$ & 0,0 & 1,9 & 2,5 & 8,9 & 1,2 & 1,6 \\
\hline As & 0,0 & 0,3 & 0,0 & 0,0 & 0,0 & 0,0 \\
\hline \multicolumn{7}{|c|}{ 2.běh (frakce vázaná v karbonátech) } \\
\hline $\mathrm{Cu}$ & 3,9 & 1,0 & 0,8 & 2,3 & 3,0 & 3,2 \\
\hline $\mathrm{Pb}$ & 47,0 & 0,0 & 0,1 & 30,1 & 4,9 & 0,1 \\
\hline $\mathrm{Ag}$ & 0,0 & 0,0 & 0,0 & 0,0 & 0,0 & 0,0 \\
\hline $\mathrm{Fe}$ & 7,7 & 24,4 & 41,0 & 189,7 & 18,4 & 27,2 \\
\hline As & 9,1 & 14,9 & 14,3 & 0,0 & 0,0 & 0,0 \\
\hline \multicolumn{7}{|c|}{ 3.běh (v oxi-hydroxidech Fe a Mn) } \\
\hline $\mathrm{Cu}$ & 7,5 & 0,5 & 0,6 & 3,0 & 2,9 & 3,0 \\
\hline $\mathrm{Pb}$ & 1409,5 & 0,3 & 2,0 & 106,5 & 124,9 & 3,9 \\
\hline $\mathrm{Ag}$ & 0,3 & 0,3 & 0,5 & 0,0 & 0,0 & 0,0 \\
\hline $\mathrm{Fe}$ & 7264,4 & 3755,9 & 3268,1 & 2482,2 & 3708,3 & 3102,5 \\
\hline As & 70,4 & 172,9 & 193,4 & 0,8 & 0,3 & 24,5 \\
\hline \multicolumn{7}{|c|}{ 4.běh (v sulfidech a organické složce) } \\
\hline $\mathrm{Cu}$ & 43,4 & 0,5 & 1,0 & 7,6 & 16,8 & 51,3 \\
\hline $\mathrm{Pb}$ & 753,0 & 0,2 & 1,8 & 35,3 & 93,4 & 3,1 \\
\hline $\mathrm{Ag}$ & 1,2 & 1,2 & 1,0 & 0,5 & 1,3 & 1,4 \\
\hline $\mathrm{Fe}$ & 3417,1 & 838,6 & 878,5 & 356,8 & 351,2 & 457,8 \\
\hline As & 539,4 & 162,1 & 201,0 & 0,2 & 0,9 & 13,5 \\
\hline
\end{tabular}




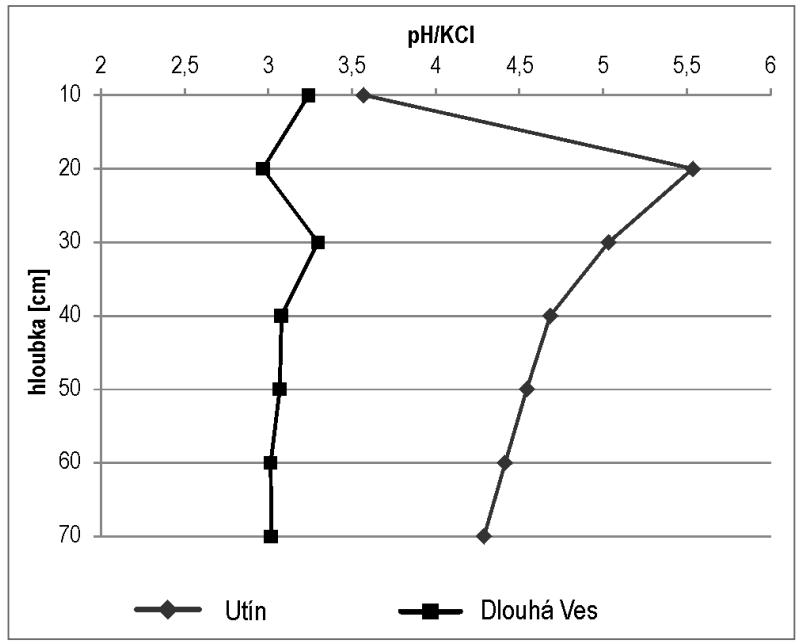

Obr. 6. Vertikální distribuce $\mathrm{pH} / \mathrm{KCl}$ v půdních profilech na lokalitách Utín a Dlouhá Ves.

Fig. 6: Vertical distribution of $\mathrm{pH} / \mathrm{KCl}$ values in soil profiles at Utín and Dlouhá Ves sites.

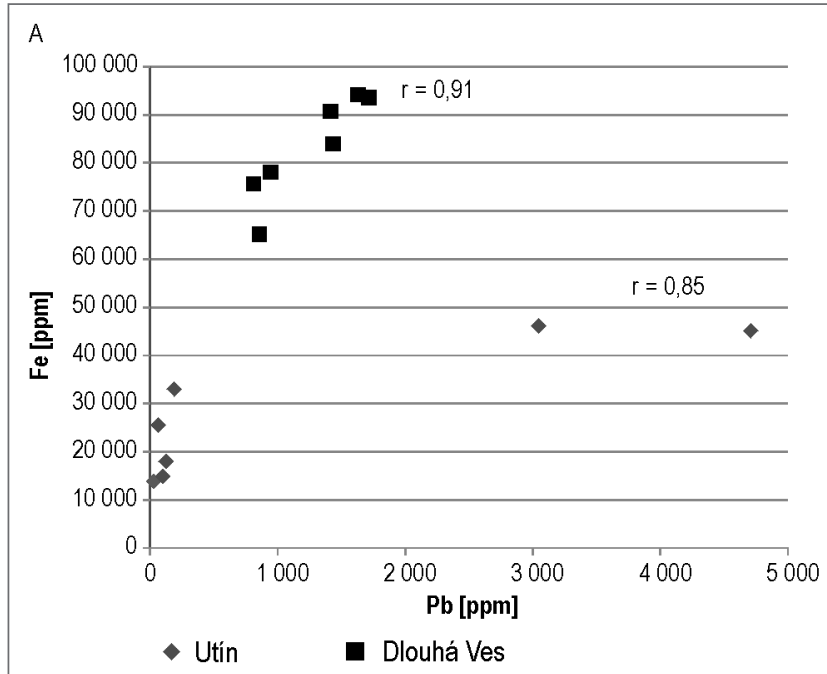

středověké lokality Utín (viz LOI, tab. 1) a obecně velmi nízký podíl jílové složky.

Silnou pozitivní korelaci $\mathrm{Pb}$ vs. $\mathrm{Cu}(\mathrm{r}=0,97)$ na lokalitě Utín můžeme vysvětlit tendencí obou prvků akumulovat se v povrchovém Ah-horizontu. V Ah-horizontu je přítomen výrazně vyšší podíl organické složky, se kterou se $\mathrm{Cu}$ váže výrazně více než $\mathrm{Pb}$. Podstatná část $\mathrm{Pb}$ se váže s oxi-hydroxidy $\mathrm{Fe}$ (obr. $3 \mathrm{~B}, \mathrm{D})$ ), které zřejmě vznikly sekundárně oxidací z původně zde těžených sulfidů. Silná pozitivní korelace $\mathrm{Pb}$ vs. Ag $(\mathrm{r}=0,99)$ je taktéž dána zvýšenou koncentrací obou prvků v povrchovém Ah-horizontu. Tuto skutečnost můžeme vysvětlit společným výskytem $\mathrm{Pb}$ a $\mathrm{Ag}$ původně v galenitu, který se v povrchovém horizontu společně s ostatními zbytkovými minerály po středověké těžbě polymetalických rud většinou zcela rozpadl na sekundární minerály. Ze vzácně dochovaných rudních minerálů byl v haldovině doložen pouze pyrit, méně častá jsou pak zrna galenitu, sfaleritu a arzenopyritu (Vávra et al. 2008).

Obr. 7: Silně pozitivní korelace koncentrací Fe vs. $\mathrm{Pb}$ a Ag vs. Cu na lokalitách Utín a Dlouhá Ves.

Fig. 7: Strongly positive correlations of $\mathrm{Fe}$ vs. $\mathrm{Pb}$ and $\mathrm{Ag}$ vs. Cu concentrations at Utín and Dlouhá Ves sites.

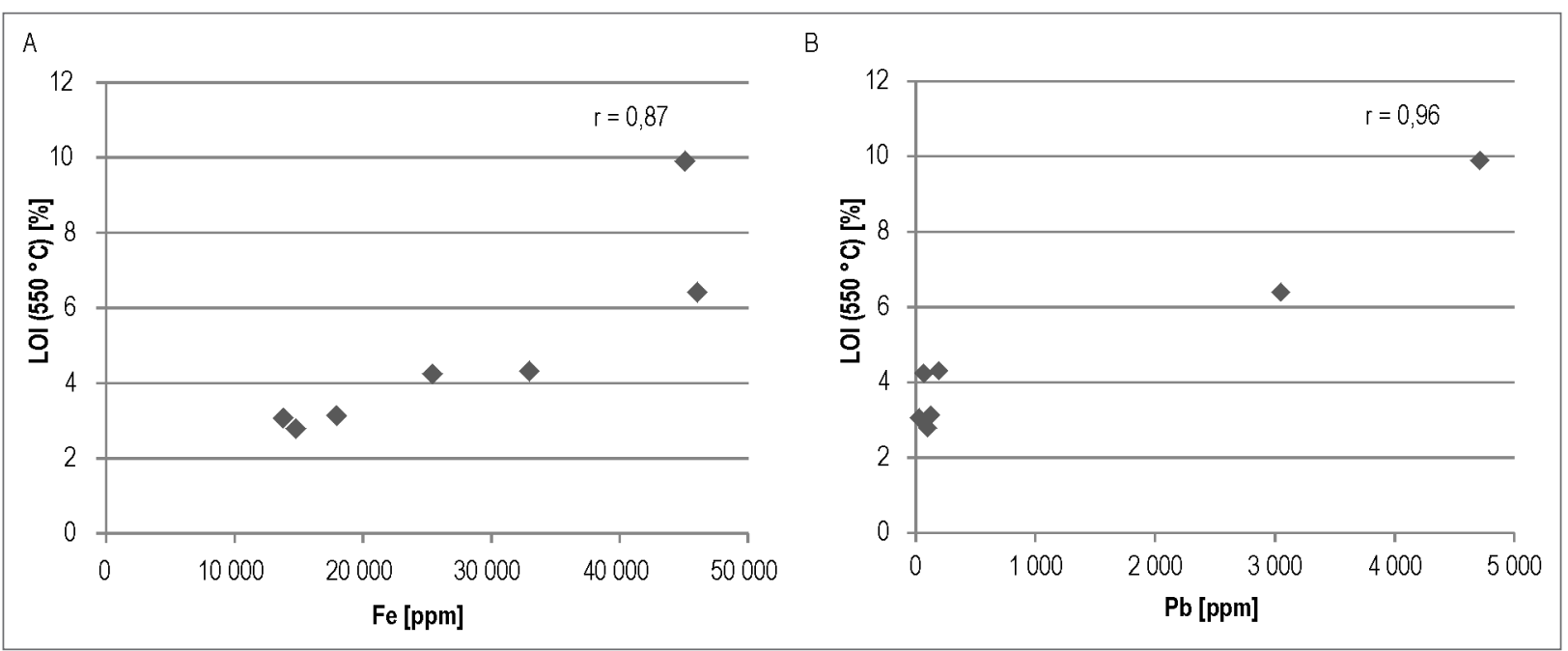

Obr. 8: Korelace koncentrací $\mathrm{Fe}$ a $\mathrm{Pb}$ vs. LOI na lokalitě Utín.

Fig. 8: Correlations of $\mathrm{Fe}$ and $\mathrm{Pb}$ concentrations vs. LOI at Utín site.

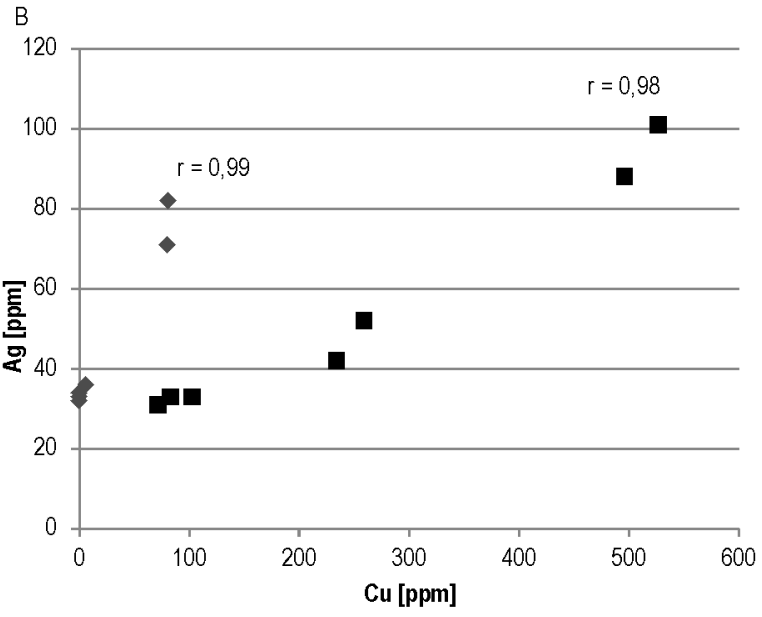


Zvýšený obsah $\mathrm{Cu}$, As a Ag ve spodní části sondy na lokalitě Dlouhá Ves $(50-70 \mathrm{~cm})$ odráží obecně silnou pozitivní korelaci Cu vs. As $(\mathrm{r}=0,96)$ a Ag vs. As $(\mathrm{r}=0,99)$. Nahromadění prvků je možné vysvětlit přítomností sekundárně vznikajících oxi-hydroxidů, na které je As primárně vázán (Gerrard 2000). Z rudních minerálů na haldě dominuje sfalerit, méně pak se vyskytují pyrhotin, pyrit chalkopyrit, arsenopyrit, aj.

Vyšší hodnoty $\chi \mathrm{v}$ prvních $20 \mathrm{~cm}$ profilu sondy Utín (obr. 5A), jsou nejspíše důsledkem přítomnosti zvýšeného podílu antiferomagnetických minerálů v podobě hematitu a sekundárně vznikajícího goethitu (Dearing 1994; Quijano et al. 2011). Tento předpoklad podporují výsledky sekvenční analýzy, ze kterých vyplývá, že většina Fe je vázána ve frakci oxi-hydroxidů Fe a Mn. K navýšení hodnot $\chi v$ této části profilu však mohl významně přispět i středověký způsob těžby, kdy na povrchu odpadních materiálů zůstaly vytěžené minerály, jež nebyly dále spotřebovány. Mohlo by se jednat především o produkty rozpadu pyritu, např. goethit či limonit (Zamarský 1981; De Vos et al. 2006). Pyrit byl z lokality popsán různými autory (Dobeš - Malý 2001; Vávra et al. 2008 aj.). Ve spodní části profilu velmi nízké hodnoty $\chi$ dokládají významný podíl převážně paramagnetických minerálů (Dearing 1994) zahrnujících zde nejspíše biotit, chalkopyrit, pyroxeny a amfiboly. Hodnoty $\chi$ naměřené $\mathrm{v}$ profilu sondy $\mathrm{u}$ Dlouhé $\mathrm{Vsi}$ odpovídají přítomnosti paramagnetických minerálů (pyrit, biotit, pyroxeny a amfiboly) a výrazně navýšená hodnota $\chi$ ve vzorku z $30 \mathrm{~cm}$ signalizuje prrítomnost antiferromagnetického hematitu (Dearing 1994). Zvýšené hodnoty $\chi$ ve vzorku z $30 \mathrm{~cm}$ v sondě u Dlouhé Vsi jsou pravděpodobně důsledkem tvorby chelátů na tomto hloubkovém rozhraní (Dearing et al. 1996). Celkově vyšší hodnoty X v profilu sondy u Dlouhé Vsi způsobují zřejmě zvětráváním vzniklé limonitické oxidy a hydroxidy a i výskyty některých $z$ této lokality doložených paramagnetických minerálů s vyšší

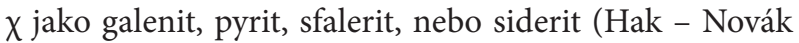
1973; Dobeš - Malý 2001; Kocourková et al. 2008; Vávra et al. 2008; Pauliš et al. 2011).

Frekvenčně závislá susceptibilita naznačuje v různé míře podíl pedogeneze na tvorbě jednotlivých půdních horizontů. Zvýšené hodnoty $\chi_{\mathrm{FD}}$ při povrchu obou sond (obr. 5B) jsou dány prýtomností humusových horizontů, vzniklých procesem více či méně intenzivní humifikace. V důsledku vnitropůdního zvětrávání vznikají sekundární minerály včetně velmi jemnozrnných superparamagnetických látek, které $\chi_{\mathrm{FD}}$ dobře detekuje (Kapička - Petrovský 2004). Zvýšené hodnoty $\chi_{\mathrm{FD}}$ ve spodních částech obou sond jsou nejspíše důsledkem nahromadění paramagnetických jílových minerálů vznikajících zvětráváním živců (Neuman 2012), napřr. horizont $C$ půdního profilu na lokalitě Utín má zvýšený podíl jílu. Hodnoty $\chi_{\mathrm{FD}} \mathrm{v}$ půdním profilu u Dlouhé Vsi jsou ve srovnání s lokalitou Utín nižší. Tato skutečnost dokládá, že pouze desítky let se vyvíjející půdní profil na lokalitě Dlouhá Ves prodělal méně intenzivní proces vnitropůdního zvětrávání ve srovnání s profilem na lokalitě Utín.

Z výsledků ztráty žíháním v profilu sondy u Dlouhé Vsi je pozorovatelný nárůst (o 2-3\%) mezi ztrátou žíháním př̀i $550{ }^{\circ} \mathrm{C}$ a při $1000{ }^{\circ} \mathrm{C}$ (tab. 1). Mohlo by to znamenat, že analyzované vzorky obsahují určité množství karbonátové složky, která se spolu s hydroxidy $(\mathrm{AlOOH})$ spaluje až při těchto vyšších teplotách (Dean 1974). Je zajímavé, že ačkoliv vzorky ze sondy u Dlouhé Vsi vykazují silně kyselou půdní reakci, výskyt karbonátů doložených $\mathrm{v}$ žilovině (siderit, dolomit-ankerit a kalcit), na lokalitě není eliminován (Kocourková et al. 2008). Významnější vazbu na karbonáty zde vykazují pouze $\mathrm{Fe}$ a $\mathrm{Pb}$, a to vždy ve vyšší části profilu (obr. 4E, F). Karbonáty v přípovrchové vrstvě haldy tedy mají patrně složení sideritu nebo ankeritu. I když na lokalitě Utín nejsou rozdíly LOI mezi $550^{\circ} \mathrm{C}$ a $1000^{\circ} \mathrm{C}$ tak velké jako v prŕípadě sondy na lokalitě Dlouhá Ves, i zde by mohl být rozdíl zapříčiněn výskytem karbonátů. Přítomnost karbonátů na lokalitě Utín se však dosud nepodařilo doložit konkrétními nálezy. Obecně nízký podíl karbonátů $\mathrm{v}$ hlušině studovaných hald může být způsoben jejich urychleným rozkladem $\mathrm{v}$ kyselém prostředí (Dobeš - Malý 2001).

\section{Pedogeneze půd na lokalitách Utín a Dlouhá Ves}

Na lokalitě Utín tmavě hnědě zbarvený (10YR 3/3) Ah-horizont ve své svrchní části půdního profilu vykazuje výraznou aciditu ( $\mathrm{pH} \sim 3,6)$, která je nejspíše výsledkem dekompozice opadanky v procesu intenzivní humifikace (viz LOI, tab. 2) a produkce organických látek s malou molekulou (s převahou fulvokyselin) v prostředí převážně jehličnatého lesního porostu. Silně kyselá reakce je zde $\mathrm{v}$ aerobním prostředí doprovázena uvolněním $\mathrm{Fe}$ a $\mathrm{Al}$ ze zvětrávajících primárních minerálů a tvorbou amorfních oxidů a hydroxidů Fe včetně hydoxi-Al iontů, které mají tendenci vysrážet se $\mathrm{v}$ písčitém rezavě hnědě zbarveném horizontu Bvs v podobě komplexních sloučenin v převažujícím procesu braunifikace (hnědnutí) s náznakem slabé podzolizace (Němeček et al. 1990). Bvs-horizont je ostře ohraničen od matečného substrátu tvořeného silně zvětralými rulami.

Ve srovnání s lokalitou Utín mají povrchové horizonty půdního profilu u Dlouhé Vsi nižší produkci dobře rozložených organických látek (viz LOI, tab. 2) svědčící o nižší intenzitě humifikačního procesu. Acidobazické vlastnosti půdního profilu u Dlouhé Vsi ve srovnání s lokalitou Utín odpovídají silně kyselému prostředí (obr. 6), přičemž tento faktor můžeme v tvorbě půd považovat za zásadní. V silně kyselém prostředí dochází ke zpomalenému rozkladu organické složky a tvorba málo mobilních organo-jílových komplexů je navíc omezena v důsledku peptizace jílových minerálů (Gerrard 2000). Nižší stupeň pedogeneze zde podporují i výsledky $\chi_{\mathrm{FD}}(1-5 \%)$.

\section{Závěry}

1. Půdy obou hald mají navzájem odlišnou povahu hlavního půdotvorného procesu, kterým je $\mathrm{v}$ př́ípadě lokality Utín humifikace doprovázená vnitropůdním zvětráváním za současného vývoje kambizemního horizontu. Rezavě hnědé zbarvení Bvs horizontu a zároveň absence eluviálního horizontu svědčí o podzolizaci, jež je doprovodným půdotvorným procesem. Ačkoli vývoj půd na obou lokalitách probíhal různě dlouhou dobu, slaběji 
vyvinutý Ah-horizont v půdním profilu na lokalitě Dlouhá Ves není jen odrazem relativně krátké doby vývoje trvajícího asi 50 let (oproti lokalitě Utín, kde se půda vyvíjela asi 700 let), ale i výrazně vyšším stupněm acidity, která zpomaluje proces humifikace a má negativní vliv i na vývoj půdních strukturních agregátů.

2. Výsledky měření $\chi_{\mathrm{FD}} \mathrm{v}$ profilu půdní sondy na lokalitě Utín ve srovnání s profilem sondy u Dlouhé Vsi dokazují vyšší intenzitu probíhajících pedogenetických procesů včetně vnitropůdního zvětrávání.

3. Výsledky SEA s přihlédnutím $\mathrm{k}$ výsledkům LOI také potvrzují vyšší stupeň vývoje půdy v profilu sondy u Utína. Ukazují, že prvky $\mathrm{Cu}, \mathrm{Pb}$, Fe a $\mathrm{Ag}$ mají v rámci frakce organických sloučenin a sulfidů tendenci vázat se převážně s organickou hmotou (v pưdním profilu u Dlouhé Vsi se prvky váží hlavně se sulfidy).

4. Oba studované půdní profily jsou silně kontaminovány především $\mathrm{As}$, méně pak $\mathrm{Pb}$ a $\mathrm{Cu}$. Vzorky z půdního profilu u Utína vykazují vyšší kontaminaci všemi zkoumanými prvky hlavně při povrchu půdního profilu, kde jsou zmíněné prvky vázány na organickou hmotu, $\mathrm{v}$ sulfidech a $\mathrm{v}$ poměrně stabilních oxi-hydroxidech Fe a Mn. Naproti tomu v půdě sondy u Dlouhé Vsi je patrný nárůst zvýšených koncentrací prvků $(\mathrm{Cu}, \mathrm{Ag}, \mathrm{As})$ směrem do hloubky. Tento vývoj je podmíněn prrítomností silně kyselého prostředí $(\mathrm{pH} / \mathrm{KCl}=3,1)$ v celém půdním profilu, ve kterém se zvyšuje uvolňování amorfních Fe-Mn komplexů, na které je zde vázán především As.

\section{Poděkování}

Rádi bychom poděkovali RNDr. Karlu Malému, Ph.D. za pomoc při volbě vhodných lokalit $k$ výzkumu. Panu Pavlu Kadlecovi děkujeme za vypracování pedochemických analýz, Mgr. Martinu Chadimovi, Ph.D. za spolupráci při měrení magnetické susceptibility. Práce vznikla za podpory specifického výzkumu na PřF MU. 


\section{Literatura}

Beneš, K. - Culek, A. - Čech, Vl. - Dudek, A. - Gotthard, J. - Havlíček, Vl. - Hinterlechner, K. - Horný, R. - Imramovský, J. - Kalášek, J. - Klein, V. - Kodym st., O. - Konta, J. - Koutek, J. - Kratochvíl, J. - Losert, J. - Matějovská, O. - Pauk, F. Rosival, A. - Soukup, J. - Stejskal, J. - Suess, F. - Suk, M. - Svoboda, J. - Vachtl, J. - Vodička, J. - Weiss, J. - Zrůstek, V. (1996): Geologická mapa ČR. List Jihlava. Mapa předčvrtohorních útvarů $1: 200000$ - ČGÚ. Praha.

Bernard, J. H. (2000): Minerály České republiky - stručný přehled. - Academia. Praha.

Bussinow, M. - Sarapatka, B. - Dlapa, P. (2012): Chemical degradation of forest soil as a result of polymellic ore mining activities. - Polish Journal of Environmental Studies, 21 (6), 1551-1561.

Čech, L. (2002): Chráněná území ČR. Jihlavsko. Okres Havličkův Brod. - Agentura ochrany př́irody a krajiny ČR a EkoCentrum. Brno.

ČGS (2012): Webová aplikace Půdní mapa 1 : 50 000, http://mapy.geology.cz/pudy/ (staženo 20. 1. 2014).

De Vos, W. - Tarvainen, T. - Salminen, R. - Reeder, S. - De Vivo, B. - Demetriades, A. - Pirc, S. - Batista, M. J. - Marsina, K. Ottesen, R. T. - O‘Connor, P. J. - Bidovec, M. - Lima, A. - Siewers, U. - Smith, B. - Taylor, H. - Shaw, R. - Salpeteur, I. - Gregorauskiene, V. - Halamic, J. - Slaninka, I. - Lax, K. - Gravesen, P. - Birke, M. - Breward, N. - Ander E. L. - Jordan, G. - Duris, M. - Klein, P. - Locutura, J. - Bel-lan, A. - Pasieczna, A., - Lis, J. - Mazreku, A. - Gilucis, A. - Heitzmann, P. - Klaver, G. - Petersell, V. (2006): Geochemical Atlas of Europe. Part 2: Interpretation of Geochemical Maps, Additional Tables, Figures, Maps, and Related Publications. - Geological Survey of Finland. Espoo, Finland.

Dean, W. E. Jr. (1974): Determination of carbonate and organic matter in calcareous sediments and sedimentary rocks by loss on ignition: Comparison with other methods. - Journal of Sedimentary Petrology, 44, 242-248.

Dearing, J. A. (1994): Environmental Magnetic Susceptibility - Using the Bartington MS2 System. - Chicago Public Library. Chicago.

Dearing, J. A. - Hay, K. L. - Baban, S. M. J. - Huddleston, A. S. - Wellington, E. M. H. - Loveland, P. J. (1996): Magnetic susceptibility of soils: an evaluation of conlicting theories using a national data set. - Geophysical Journal International, 127, 728-734.

Dobeš, P. - Malý, K. (2001): Mineralogie polymetalických rudních výskytů ve střední části havlíčkobrodského revíru. - Vlastivědný sborník Vysočiny, odd. věd prrírod., 15, 51-85. Jihlava.

Gerrard, J. (2000): Fundamentals of Soils. - 11 New Fetter Lane. London.

Gobat, J. M. - Aragio, M. - Matthey, W. (2004): Fundamentals of soil science and biology. 1-602. Science Publisher inc., Enfield, New Hampshire.

Hak, J. - Novák, F. (1973): Mineralogie a geochemie ložiska Dlouhá Ves u Havlíčkova Brodu. - In: Sborník hornická Př́ibram ve vědě a technice, sekce geol. ložiska nerost. surovin, G17, 247-262. Př́ibram.

Juráček, J. (2010): Strukturně geologické výzkumy širšího okolí Stř́íbrných hor. - MS, rešerše. ÚGV PřF MU. Brno.

Kapička, A. - Petrovský, E. (2004). Magnetismus hornin a jeho aplikace při studiu znečištění životního prostředí. - Československý časopis pro fyziku, 54 (4), 240-243

Karczewska, A. - Bogda, A. - Gałka, B. - Szulc, A. - Czwarkiel, D. - Duszyńska, D. (2006): Natural nad anthropogenic soil enrichment in heavy metals in areas of former metallic ore mining in the Sudety Mts. - Polish Journal of Soil Science. 39 (2), 131-142. Lublin.

Kocourková, E. - Cempírek, J. - Losos (2008): Kaňkit z Dlouhé Vsi u Havlíčkova Brodu. - Acta rerum naturalium, 4, 7-12.

Králík M. et al. (1985): Zhodnocení prognózních zdrojů Ag v Českém masivu. - MS, Geoindustria Praha. Geofond Praha. Praha.

Ministerstvo životního prostředí (1994): Vyhláška MŽP č. 13/1994 Sb. o ochraně zemědělského půdního fondu, on-line: http:// www.mzp.cz/C1257458002F0DC7/cz/ poskozeni_pudy_kontaminaci/\$FILE/OOHPP-Poskozeni_\%20pudy_kontaminaci-081119.pdf (24. 2. 2014).

Mísař, Z. - Dudek, A. - Havlena, V. - Weiss, J. (1983): Geologie ČSSR I. Český masív. - SPN. Praha.

Neuman, P. (2012): Vztah mezi susceptibilitou, chemickým a mineralogickýcm složením Fe rud. - MS, diplomová práce, ÚGV PřF MU. Brno.

Němeček, J. - Smolíková, L. - Kutílek, M. (1990): Pedologie a paleopedologie. - Academia, Praha

Němeček, J. (2001): Taxonomický klasifikační systém půd České republiky. - Česká zemědělská univerzita. Praha.

Pauliš, P. - Kopecký, S. - Jebavá, I. (2011): Nové nálezy supergenní mineralizace v havlíčkobrodském rudním revíru (ČR). - Bulletin mineralogicko-petrologického oddělení Národního muzea v Praze, 19/1, 76-82. Praha.

Quijano, L. - Gaspar, L. - Chaparro, M. A. E. - Navas, A. (2011): Magnetic Susceptibility in Topsoils and Bulk Cores of Cultivated Calcisoils. - Latinmag Letters, 1, 1-6, Tandil (Argentina).

Sencindiver, J. C. - Ammons, J. T. (1997): Minesoil Genesis and Classification. - Minesoils of the United States, 12, 1-13.

Stránský, K. - Buchal, A. - Winkler, Z. (2002): Simtany u Havlíčkova Brodu - stopy po těžbě a hutnickém zpracování stř́ibrných rud. - Archeologia technica, 14, 21-26.

Tessier, A. - Campbell, P. G. - Bisson, M. (1979): Sequential extraction procedures for the specification of particulate trace metals. - Analytical Chemistry, 5, 844-855.

Vávra, V. - Štelcl, J. - Malý, K. (2008): Průvodce po geologických zajímavostech kraje Vysočina. - Muzeum Vysočiny Jihlava. Jihlava. Zamarský, V. (1981): Mineralogie systematická I. díl. - VŠ báňská v Ostravě. Ostrava. 